TAPROBANICA, ISSN 1800-427X. November, 2020. Vol. 09, No. 02: pp. 227-231, pl. 64.

(C) Research Center for Climate Change and Department of Biology, Faculty of Mathematics \& Natural Sciences, University of Indonesia, Depok 16424, INDONESIA.

http://www.taprobanica.org/

https://doi.org/10.47605/tapro.v9i2.238

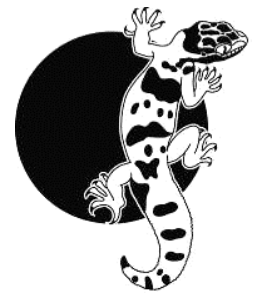

\section{Round-eared tube-nosed bat (Murina cyclotis) from Southwest Sri Lanka}

Vesper bats (Family Vespertilionidae) are the most diverse bat family in Sri Lanka, represented by 12 species (Yapa \& Ratnavira 2013, Yapa 2017, Edirisinghe et al. 2018, Kotagama \& Goonatilake 2019). The roundeared tube-nosed bat, Murina cyclotis is one of the rarest vesper bats (Yapa 2017). The species is distributed in South and Southeast Asia (Corbet \& Hill 1992, Bates \& Harrison 1997), and it belongs to a cryptic species complex (Francis et al. 2010, Soisook et al. 2013). The distribution range of $M$. cyclotis is patchy and in Sri Lanka it is known only from a few localities (Phillips 1932, 1935, 1980, Bates \& Harrison 1997, Menon 2003, Francis 2008). Given its widespread range, it is listed as Least Concern in the International Union for the Conservation of Nature (IUCN) Red List, whereas the National Conservation Assessments of Sri Lanka listed M. cyclotis as Near Threatened (NT) (IUCNMOE 2012). Here, we provide a new site record for this species from southwestern Sri Lanka.

The range extension is from the vicinity of an ancient Buddhist monastery, Bambaragala Aranya Senasanaya $\left(6.512750^{\circ} \mathrm{N}, 80.748667^{\circ}\right.$ E, alt. $\sim 150 \mathrm{~m}$ a.s.l.) in Pallebedda, Ratnapura District, Sabaragamuwa Province, Sri Lanka (Fig. 1). The locality is in the lowland intermediate bio-climatic zone (annual mean rainfall is $1500-2000 \mathrm{~mm}$ and temperature is $27.8-29.6^{\circ} \mathrm{C}$ ). Visual encounter surveys were carried out for a period of six days (25-30 July 2016) in dry-mixed evergreen forests in the monastery grounds involving four trained field biologists, during both the day (08:00-14:00 h) and night (18:00-21:30 h). Microbats encountered at the site were captured using hand nets (net depth: $45 \mathrm{~cm}$, net diameter: $30 \mathrm{~cm}$, mesh size: $1.5 \times 1.5 \mathrm{~mm}$ ). For all bats captured, standard length measurements (following Srinivasulu et al. 2010) were taken using digital vernier callipers (Type RD 10) in the field.
Morphological characteristics and body coloration were also documented. The captured bats were identified to the species level based on Phillips (1935), Corbet \& Hill (1992), Bates \& Harrison (1997), and Srinivasulu et al. (2010 prior to releasing. Air temperature and relative humidity were measured using a multi-digital hygrometer (TA-138, China), and wind speed using a digital anemometer (MS-6252-A, China). A Garmin Etrex handheld GPS receiver was used to georeference the roosting sites.

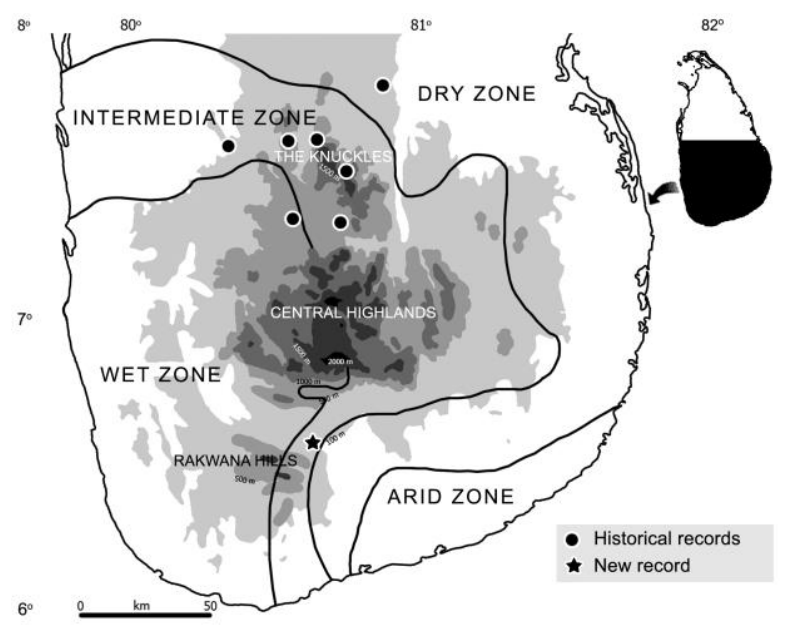

Figure 1. Distribution of Murina cyclotis in Sri Lanka. Historical locations are based on Phillips (1935), Bates \& Harrison (1997), Yapa \& Ratnavira (2013), Yapa (2017); Map ㄷ A.A.T. Amarasinghe

Two specimens of M. cyclotis (male and female) were captured at 10:19 h on 27 July 2016, while they were roosting on the underside of a large, dry leaf of narrow woolly-stipuled lotus croton, Macaranga peltata (Family Erythroxylaceae). This roosting site $(1.8 \mathrm{~m}$ in height) had about 45-60\% canopy cover. During the time of observation, the wind speed was 0.72 $-1.44 \mathrm{~km} / \mathrm{h}$ (average $1.68 \mathrm{~km} / \mathrm{h}$ ), ambient temperature was $26.8-28.2{ }^{\circ} \mathrm{C}$ (average 26.7 ${ }^{\circ} \mathrm{C}$ ), and humidity ranged between $69-76 \%$ (average 69.5\%). The bats remained in this roosting site during the daytime and emerged to forage in the evening $(18: 45 \mathrm{~h})$. These individuals flew very slowly along a walking 
trail about one meter above the ground. They had golden fur coloration throughout the body (Fig. 2). The morphometric variables and morphological characteristics are provided in Tables 1 and 2. In addition to M. cyclotis, Rhinolophus rouxii, Hipposideros speoris, Megaderma spasma, Kerivoula picta and Cynopterus sphinx were also observed foraging along the same footpath. Our observations of $M$. cyclotis are in agreement with the current knowledge of its autecology. In South Asia, this species is considered a forest dweller and roosts among leaves of cardamom plantations nested in forested landscapes as well as in caves in small colonies (Molur et al. 2002, Yapa 2017). Its low-flying behaviour while foraging has also been recorded elsewhere (Bates \& Harrison, 1997, Aul et al. 2014). Both the habitat and the regional landscape in the study area can be described as predominantly forested lands (Fig. 3 ), which matches the previous observations in
Southeast Asia and mainland South Asia where $M$. cyclotis occurred in less-disturbed lowland forests and lower montane forests (Phillips 1932, 1935, Nowak 1991, Rickart et al. 1991, Ruedas et al. 1994, Yapa \& Ratnavira 2013).

However, this species had previously been recorded in Sri Lanka only from Gammaduwa, Mousakanda, Kandy, and Matale (Phillips 1935); Medamahanuwera (Bates \& Harrison 1997); Kurenegala (Yapa \& Ratnavira 2013); and Wasgamuwa (Yapa 2017). Most of the historical records (before 1970) were reported in and around the central highlands of Sri Lanka. Thus, our observation is the first record for this species from the lowland forests of the intermediate bioclimatic zone of Ratnapura District in the south of the island. Based on our observations and earlier records (Bates \& Harrison 1997, Phillips 1935, Soisook et al. 2013), $M$. cyclotis is likely a species restricted to forested areas, including secondary forests.

Table 1. Morphometric variables recorded from Murina cyclotis specimens from the Bambaragala Aranya Senasanaya, Sri Lanka, and comparisons with Phillips (1935) and Bates \& Harrison (1997); measurements in $\mathrm{mm} ;$ - not measured.

\begin{tabular}{|c|c|c|c|c|c|}
\hline \multirow[b]{2}{*}{ Measurement } & \multicolumn{2}{|c|}{ This study } & \multicolumn{2}{|c|}{ Phillips (1935) } & \multirow{2}{*}{$\begin{array}{c}\text { Bates \& Harrison (1997) } \\
\begin{array}{c}\text { Males and Females } \\
(n=\text { unknown })\end{array}\end{array}$} \\
\hline & $\begin{array}{l}\text { Male } \\
(n=1)\end{array}$ & $\begin{array}{c}\text { Female } \\
(n=1)\end{array}$ & $\begin{array}{c}\text { Male } \\
(n=10)\end{array}$ & $\begin{array}{c}\text { Female } \\
(n=2)\end{array}$ & \\
\hline Head and Body length & 41.1 & 44.2 & $46.0-48.0$ & 48.5 & $38.0-50.0$ \\
\hline Ear length & 14.5 & 13.6 & $14.0-15.0$ & $13.7-15.5$ & $13.0-16.0$ \\
\hline Ear width & 9.1 & 8.4 & - & - & - \\
\hline Tragus length & 7.7 & 6.1 & - & - & - \\
\hline Tragus width & 2.1 & 1.6 & - & - & - \\
\hline Forearm length & 31.9 & 32.0 & $30.6-31.0$ & $32.5-33.0$ & $29.7-34.5$ \\
\hline Thumb $+1^{\text {st }}$ claw length & 6.8 & 8.3 & - & - & - \\
\hline $2^{\text {nd }}$ metacarpal & 27.2 & 27.7 & - & - & - \\
\hline $3^{\text {rd }}$ metacarpal & 30.2 & 30.3 & - & - & $27.3-32.3$ \\
\hline $4^{\text {th }}$ metacarpal & 29.3 & 28.6 & - & - & $27.1-31.5$ \\
\hline $5^{\text {th }}$ metacarpal & 29.7 & 29.7 & - & - & $27.6-32.0$ \\
\hline 1ph $3 \mathrm{mt}$ length & 13.5 & 14.4 & - & - & - \\
\hline 2ph $3 \mathrm{mt}$ length & 16.5 & 18.3 & - & - & - \\
\hline 1ph $4 \mathrm{mt}$ length & 10.1 & 10.5 & - & - & - \\
\hline 2ph 4mt length & 9.9 & 10.3 & - & - & - \\
\hline $1 \mathrm{ph} 5 \mathrm{mt}$ length & 9.9 & 10.1 & - & - & - \\
\hline 2ph 5mt length & 9.4 & 10.2 & - & - & - \\
\hline Wingspan length & 220.0 & 220.0 & 229.0 & - & - \\
\hline Penis length & 3.4 & — & - & - & - \\
\hline Penis width & 1.5 & - & - & - & - \\
\hline Testicle length & 1.8 & - & - & - & - \\
\hline Testicle width & 1.7 & - & - & - & - \\
\hline Tibia length & 17.4 & 17.6 & - & - & - \\
\hline Calcar length & 12.5 & 19.0 & - & - & - \\
\hline Hind foot length & 7.3 & 9.1 & $6.8-8.0$ & $8.0-9.0$ & $7.0-10.0$ \\
\hline Tail length & 29.0 & 32.5 & $33.2-34.0$ & 34.0 & $32.0-41.0$ \\
\hline
\end{tabular}




\section{Plate 64}
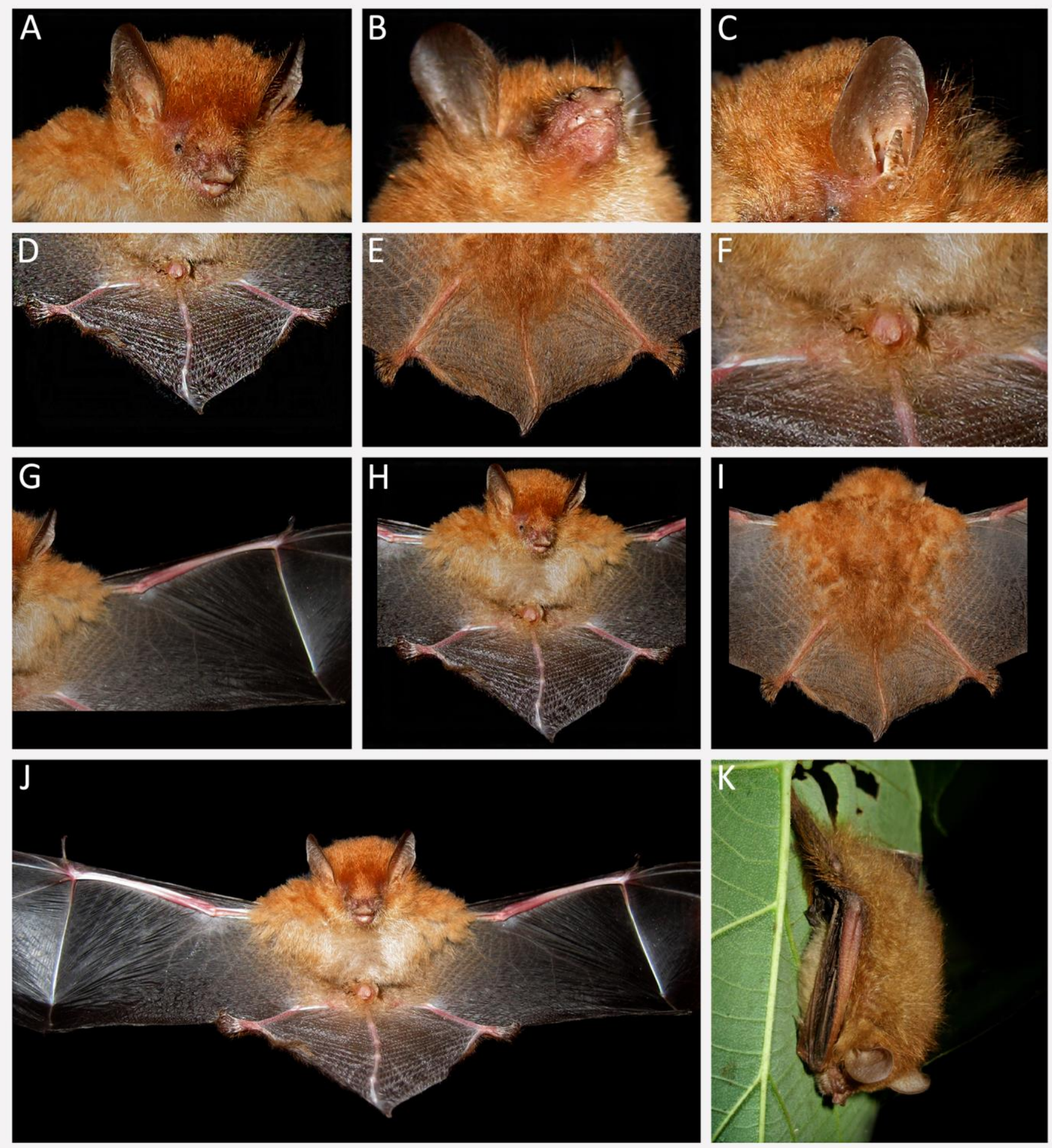

Figure 2. Unique characters of Murina cyclotis specimen (a male) recorded from Bambaragala, Sri Lanka: (A) facial structure, (B) throat area [see the fur colour], (C) external ear lobe and tragus; (D) ventral and (E) dorsal aspects of the semitransparent interfemoral (tail) membrane, (F) short light brown hairs around penis and the scrotum, (G) ventral aspect of the wing membrane (patagium); (H) ventral and (I) dorsal aspects of the body including the proximal parts of the patagium, $(\mathbf{J})$ ventral aspect of the expanded wings; and $(\mathbf{K})$ a different individual (a female) at the roosting site, on a Macaranga peltata tree (Family Euphorbiaceae). 


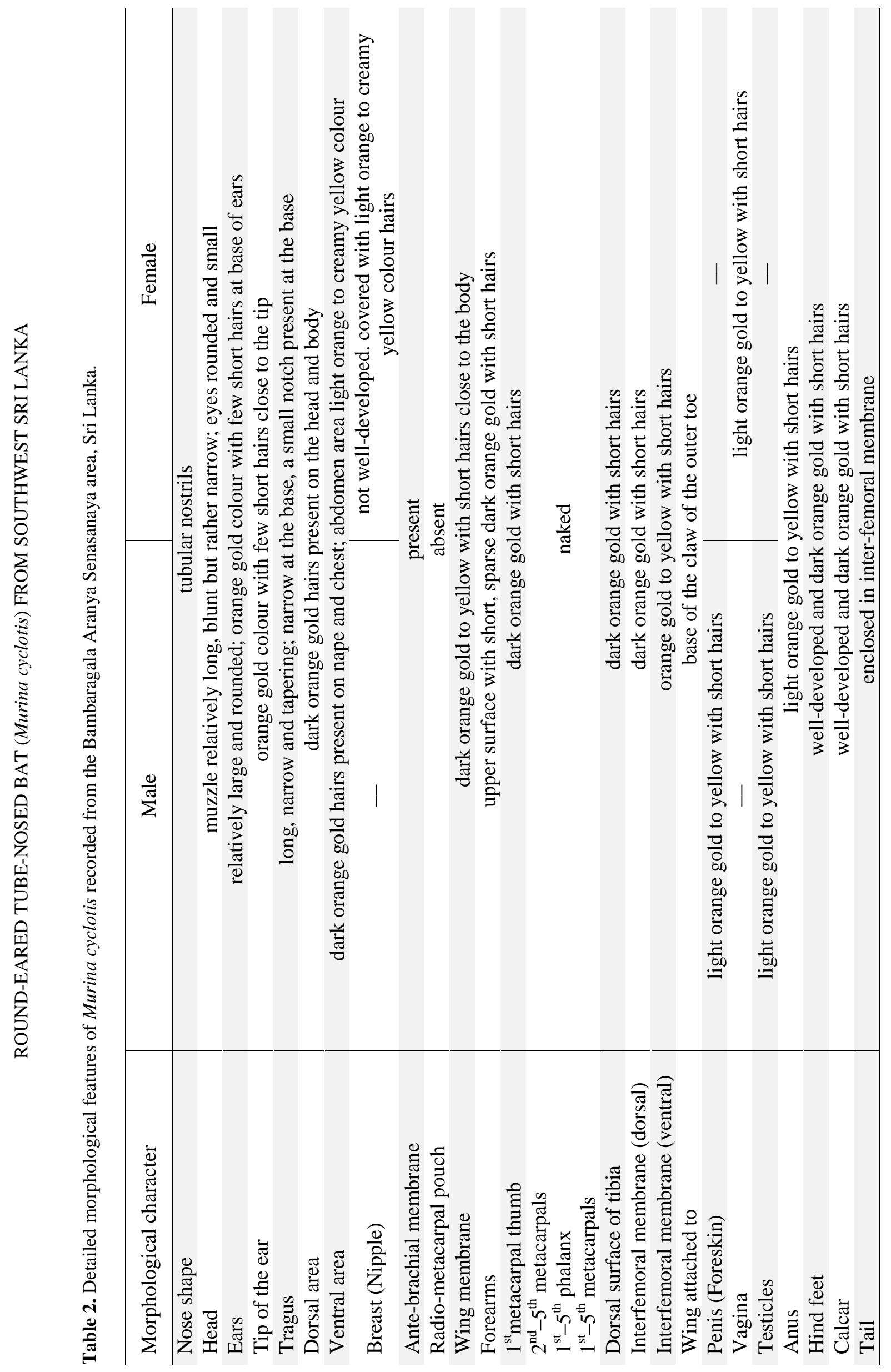


The distribution, taxonomy, ecology and the status of most of the chiropterans, especially microbats in Sri Lanka, are poorly known. Recent documentation of new site records and distribution of lesser known species of bats in Sri Lanka highlights the need for more extensive studies to understand the distribution and habitat preference of bats to augment historical records (Rubsamen et al. 2004, Nanayakkara et al. 2012, Edirisinghe et al. 2013, 2020a-b, WellappulliArachchi et al. 2014). Such new studies will play a crucial role in the conservation of these species (Dittus 2017).
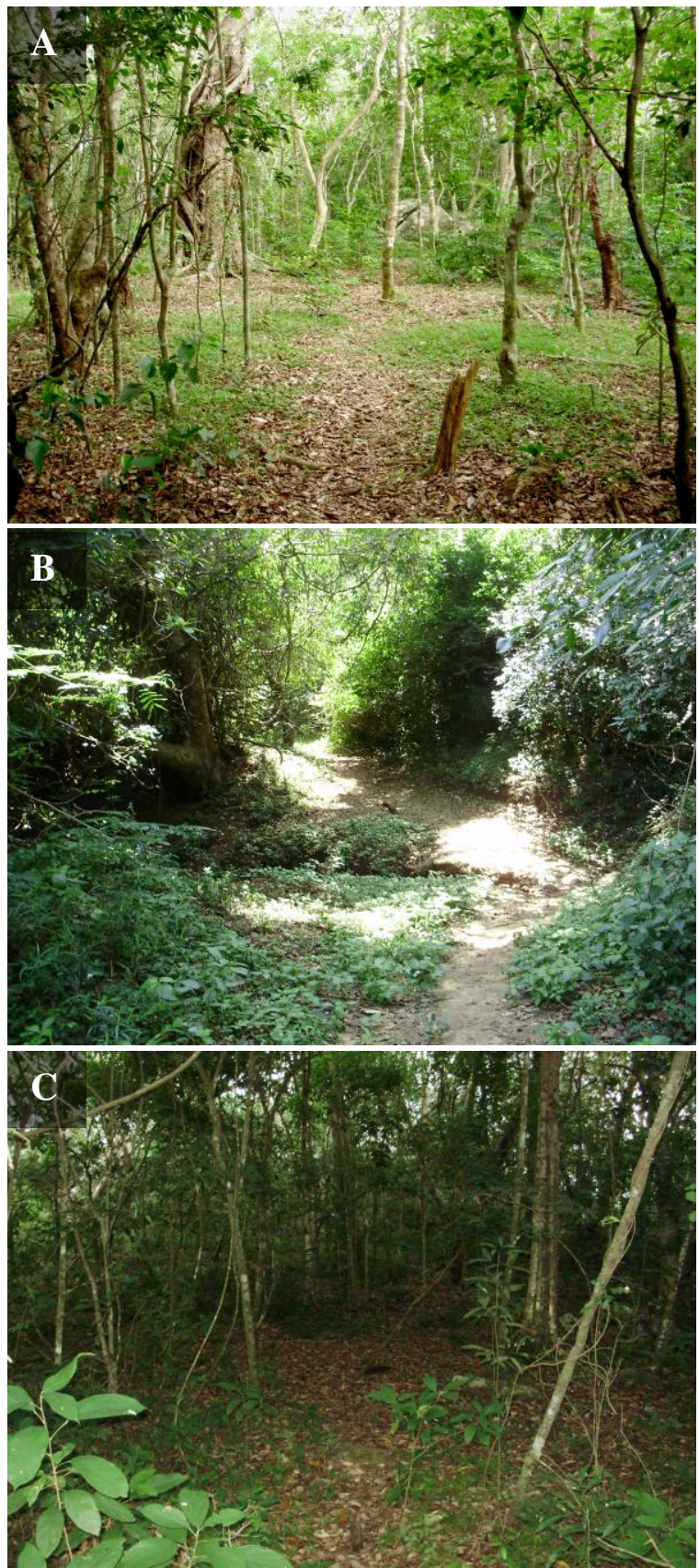

Figure 3. Some habitats of Murina cyclotis in Bambaragala, Sri Lanka: (A) tall forest, (B) dense forest along the foot path, and (C) dense shady forest.

\section{Acknowledgements}

We thank Ven. Weherawaththe Indrasumana Thero (chief incumbent) and other reverend theros of Bambaragala Monastery, Naveen Kumara, Dammika Wijesinghe and villagers for their support during the field work. Also, we thank Burton Lim (Royal Ontario Museum, Canada), Thasun Amarasinghe (University of Indonesia), Suranjan Karunarathna (NEET, Sri Lanka), and Philip Bowles (IUCN) for constructive comments that helped to improve the manuscript.

\section{Literature cited}

Aul, B., P. Bates, D. Harrison, G. Marimuthu (2014). Diversity, distribution and status of bats on the Andaman and Nicobar Islands, India. Oryx, 48 (2): 204-212.

Bates, P.J.J. and D.L. Harrison (1997). Bats of the Indian Subcontinent. Harrison Zoological Museum, Kent: 258pp.

Corbet, G.B. and J.E. Hill (1992). The mammals of the Indomalayan Region: a systematic review. Natural History Museum Publications, Oxford University Press: 488pp.

Dittus W.P. (2017). The biogeography and ecology of Sri Lankan mammals point to conservation priorities. Ceylon Journal of Science, 46 (5): 33-64.

Edirisinghe, G.M., B.S.A.T.H. Sudasinghe, and Y. Mapatuna (2013). Evidence of Saccolaimus saccolaimus (Chiroptera) roosting in a building in Sri Lanka. Taprobanica, 5 (1): 9496.

Edirisinghe, G., T. Surasinghe, D. Gabadage, M. Botejue, K. Perera et al. (2018). Chiropteran diversity in the peripheral areas of the Maduru-Oya National Park in Sri Lanka: insights for conservation and management. Zookeys, 784: 139-162.

Edirisinghe, G., D. Gabadage, M. Botejue, D. Dissanayake, P. Chandika et al. (2020a). Lesser large-footed Bat (Myotis hasseltii) from Southwest Sri Lanka. Taprobanica, 9 (2): 232-236.

Edirisinghe, G., S. Akmeemana, S. Yaddehige, D. Gabadage, M. Botejue et al. (2020b). Chocolate pipistrelle (Hypsugo affinis) from Hantana, Sri Lanka after 87 years. Taprobanica, 9 (2): 237-241.

Francis, C.M. (2008). A Field Guide to the Mammals of South East Asia. New Holland Publishers, UK: 392pp.

Francis C.M., A.V. Borisenko, N.V. Ivanova, J.L. Eger, B.K. Lim et al. (2010). The role of DNA barcodes in understanding and conservation of 
mammal diversity in Southeast Asia. PLoS One, 5 (9): e12575.

IUCN-MOE (2012). The National Red List 2012 of Sri Lanka: Conservation Status of the Fauna and Flora. Ministry of Environment, Colombo, Sri Lanka: 476pp.

Kotagama, S. and S. de. A. Goonatilake (2019). Pictorial Pocket Guide to the Mammals of Sri Lanka (revised \& expanded edition 2019). Field Ornithology Group of Sri Lanka: 148pp.

Menon, V. (2003). A Field Guide to Indian Mammals, Dorling Kindersley (India) Pvt. Limited: 201pp.

Molur, S., G. Marimuthu, C. Srinivasulu, S. Mistry, A.M. Hutson et al. (eds.) (2002). Status of South Asian Chiroptera: Conservation Assessment and Management Plan (C.A.M.P.) Workshop Report, 2002. Zoo Outreach Organisation, CBSG South Asia and WILD, Coimbatore: 320pp.

Nanayakkara, R.P., N. Vishvanath, and T.G.T. Kusuminda (2012). Re-discovery of pouch bearing sheath tailed bat Saccolaimus saccolaimus Temminck (Chiroptera: Emballonuridae) from Sri Lanka after 75 years. Asian Journal of Conservation Biology, 1 (2): $134-137$.

Nowak, R.M. (1991). Walker's Mammals of the World Fifth Edition Volume 1, The Johns Hopkins University, Maryland: 657pp.

Phillips, W.W.A. (1932). Additional to the fauna of Ceylon - part II. Some new and interesting bats from the hills of the Central Province. SpoliaZeylanica, 16 (1): 329-335.

Phillips, W.W.A. (1935). A Manual of the Mammals of Ceylon. Dulau \& Company, London: 373pp.

Phillips, W. W. A. (1980). Manual of the Mammals of Sri Lanka - Part 1, 2nd Revised Edition., Wildlife and Nature Protection Society of Sri Lanka, Colombo: 267pp.

Rickart E.A., L.R. Heaney, and R.C. Utzurrum (1991). Distribution and ecology of small mammals along an elevational transect in southeastern Luzon, Philippines. Journal of Mammalogy, 72 (3): 458-469.

Rubsamen, R., M. Eckrich, and H.H. Costa (2004) Cave dwelling bats in Sri Lanka, Spolia Zeylanica, 41: 102-109.
Ruedas L., J. Demboski, and R. Sison (1994). Morphological and ecological variation in Otopteropus cartilagonodus Knock, 1969 (Mammalia: Chiroptera: Pteropodidae) from Luzon, Philippines. Proceeding of Biological Socierty Washington, 107 (1): 1-16.

Soisook, P., S. Karapan, C. Satassok, V. Dinh Thong, F.A. Anwarali Khan et al. (2013). A review of the Murina cyclotis complex (Chiroptera: Vespertilionidae) with descriptions of a new species and subspecies. Acta Chiropterologica, 15: 271-292.

Srinivasulu, C., P.A. Racey, and S. Mistry (2010). A key to the bats (Mammalia: Chiroptera) of South Asia. Journal of Threatened Taxa, 2 (7): 1001-1076.

Wellappulli-Arachchi, S.M., W.G.M. Edirisinghe, D.S.B. Dissanayake, Y. Mapatuna, and S. Wickramasinghe (2014). A breeding colony of the brown bat (Myotis hasseltii) from Sri Lanka. Taprobanica, 6 (1): 68-71.

Yapa, W. (2017). A Field Guide to the Bats of Sri Lanka. Dilmah Ceylon Tea Company PLC, Colombo, Sri Lanka: 142pp.

Yapa, A. and G. Ratnavira, 2013. The Mammals of Sri Lanka. Field Ornithology Group of Sri Lanka, University of Colombo, Colombo, Sri Lanka: 1009pp.

Submitted: 5 March 2020, Accepted: 12 June 2020 Section Editor: Burton Lim

G. Edirisinghe ${ }^{1,5}$, D. Gabadage ${ }^{1}$, M. Botejue ${ }^{1,4}$ P. Chandika ${ }^{2}$ \& T. Surasinghe ${ }^{3}$

${ }^{1}$ Biodiversity Conservation Society, 150/6, Stanly Thilakaratne Mw., Nugegoda 10250, Sri Lanka ${ }^{3}$ Hatangala, Balangoda 70100, Sri Lanka

${ }^{3}$ Department of Biological Sciences, Bridgewater State University, Bridgewater, MA 02325, USA

${ }^{4}$ Central Environmental Authority, 104, Denzil Kobbekaduwa Mw., Battaramulla 10120, Sri Lanka ${ }^{5}$ E-mail: gayan.yza@gmail.com 